\title{
A Review on Rotating Biological Contactors
}

\author{
Sharjeel Waqas, Muhammad Roil Bilad* \\ Department of Chemical Engineering, Universiti Teknologi PETRONAS, Bandar Seri Iskandar, Perak 32610, \\ Malaysia \\ * Correspondence: E-mail: mroil.bilad@utp.edu.my
}

\begin{abstract}
A B S T R A C T
Rotating biological contactors (RBC) is a wastewater treatment process that provides a both acceptable effluent quality and organic removal efficiency at a comparatively very low costs. It is highly attractive due to simplicity of operation, low sludge production, small foot-print, low maintenance, and low operational cost. Complete nitrification/denitrification can be achieved by varying the disk submergence level and operating the process under both anaerobic/anoxic conditions in a single unit. In this review, pros and cons of RBC are discussed in detail along with the factors affecting its performances. Organic and hydraulic loading and hydraulic retention time are the main parameters followed by additional parameters such as rotational speed, media, disk submergence, dissolved oxygen level, influent and effluent characteristics, and step-feeding in affecting the performance of an RBC system. RBC has shown promising results for the removal of biodegradable matter, nitrogen and phosphorous removal. The approaches for hybridization of biological processes to improve their overall performance are also review. Such success story is assess so explore possibility of developing RBC based hybrid processes. Hybrid RBC can be form from in-combination with other processes for minimizing energy requirements and maximizing the efficiency of the system.
\end{abstract}

\author{
ARTICLE INFO

\section{Article History:} \\ Submitted/Received 28 Aug 2018 \\ First revised 03 Nov 2018 \\ Accepted 07 Jan 2019 \\ First available online 09 Jan 2019 \\ Publication date 01 Sep 2019
}

\section{Keyword:}

Attached growth process,

Biological wastewater treatment, Mocroorganisms,

Rotating biological contactors 


\section{INTRODUCTION}

Wastewater treatment processes ought to follow standards that help to ensure environmental sustainability (Pebriyanti et al., 2016). A variety of physical, chemical, and biological processes are used for wastewater treatment. All of them have their own merits and limitations (Rajasulochana and Preethy, 2016). For example, high effluent quality is achieved by traditional biological processes in expenses of high energy usage largely for reactor aeration. It accounts for about 55\% of the total energy budget for wastewater treatment. Development of a wastewater treatment technology can further improve effluent quality and increase pollutants removal efficiency (Hoyland et al., 2010).

Secondary wastewater treatment is a biological process that employs an ample variety of microorganisms, primarily bacteria. These microorganisms; contained in wastewater; transform biodegradable organic matter into basic substances and extra biomass (Lee et al., 2001). Biological treatment processes include attached growth and suspended growth processes. For the former, microorganisms are attached to a solid surface, while for the latter, the microorganisms are in suspension . Trickling filters and rotating biological contactor (RBC) are attached growth processes while activated sludge (AS) process and membrane bioreactor (MBR) are the suspended growth processes. These biological treatment methods are employed worldwide to treat domestic and industrial wastewater (Wiszniowski et al., 2006).

RBC is the attached growth process in which microorganisms are attached to a media by developing a film. RBC constitutes a precise distinctive and superior substitute process for biodegradable matter as well as nitrogen removal. Some of the potential advantages of RBC as compared to conventional AS and trickling filter process are as follows: low land requirement, simple process control and monitoring, little operational and maintenance costs, high biomass concentration, low excess sludge production, short hydraulic retention time, high oxygen transfer efficiency, no need of sludge recirculation, process is resistant to shock and toxic loads and compact design (Cortez et al., 2008; Patwardhan, 2003; Rodgers and Zhan, 2003).

\section{ROTATING BIOLOGICAL CONTACTORS}

The RBC was first originated in Germany in 1920s and was first described as a "rotating aerobic mass" fixed to a media support(Chan and Stenstrom, 1981). The first plant was registered in the United States and was named the "contact filter" or "biological wheel" (Doman, 1929). Commercial importance in RBC was nominal, until the development of drip body immersion system. This leads to the development of first experimental pilot scale RBC. This milestone study opened new ways for future RBC design which evolved in the 1960s (Hassard et al., 2015). Historically, RBC have been used for the treatment of wastewater for organic carbon removal. The use of this process was later expanded to include nitrification and denitrification of wastewater. Early RBC systems began in Europe and have been in continuous operation since 1958 (Poon et al., 1979). A schematic diagram of RBC is shown in Figure 1.

\subsection{Types}

RBC consists of two main types; integral and modular. Integral systems consist of a single unit combining all three steps i.e., primary settlement, RBC biological zone and final clarifier. Integral systems have a treatment capacity of $\leq 250$ population equivalents (PE) (Findlay, 1993). Modular systems, on the other hand, consists of separate units for primary treatment, RBC biological process and solids treatment and have a treatment capacity of PE $>1000$. The treatment capacity allows more flexible configurations (Griffin and Findlay, 2000). Parallel flow arrangement of RBC can be 
operated for acceptable loading limits. But if the effluent quality is a matter of concern, RBC is placed in series. $40 \%$ submergence of the disc is usually used (Cortez et al., 2008). If submergence is increased, less oxygen is supplied to the microorganism and conditions in the reactor becomes anaerobic and the process becomes favorable for denitrification (Teixeira and Oliveira, 2001).

RBC is a wastewater treatment process that provides a both acceptable effluent quality and organic removal efficiency at a comparatively very low costs. It is highly attractive due to simplicity of operation, low sludge production, small foot-print, low maintenance and low operational cost. Complete nitrification/denitrification can be achieved by varying the disk submergence level and operating the process under both anaerobic/anoxic conditions in a single unit. In this review, pros and cons of RBC are discussed in detail along with the factors affecting its performances. Organic and hydraulic loading and hydraulic retention time are the main parameters followed by additional parameters such as rotational speed, media, disk submergence, dissolved oxygen level, influent and effluent characteristics, and step-feeding in affecting the performance of an RBC system. RBC has shown promising results for the removal of biodegradable matter, nitrogen and phosphorous removal. The approaches for hybridization of biological processes to improve their overall performance are also review. Such success story is assess so explore possibility of developing RBC based hybrid processes. Hybrid RBC can be form from in-combination with other processes for minimizing energy requirements and maximizing the efficiency of the system.

\subsection{Advantages}

RBC is preferable for wastewater treatment because of its simplicity, low operating and maintenance costs and reliable performance (Cortez et al., 2008). A variety of process parameters for RBC has been discussed in the literature. The operational expenditure and maintenance cost of the RBC is less than the AS process. In AS process, aeration cost is much higher which increases the operational cost of the overall process. In RBC, no aeration is required due to the direct contact of media with the air through rotation of the disks. The capital expenditure for RBC is inversely proportional to the particulate equivalents. The capital cost for RBC is less than the AS process because of the less requirement of material. The energy usage is about half of the AS process because of no need of aeration (Hassard et al., 2015).

$\mathrm{RBC}$ process is resistant to the toxic and shock loads making it a more reliable process to be used for wastewater treatment. The microorganisms in the RBC are attached to the media and biodegradation occurs at the media surface. With the rise in organic loading, the microorganisms do not wash out, making the process more feasible to handle organic shock loads. The same is the case for the increase in toxic loads, more food is available to the microorganism. AS process has microorganisms in the suspended form so any rise in load will wash out the suspended microorganisms and results in poor treatment. An increase in hydraulic and organic loading will wash out the microorganisms (Kapoor et al., 2003). The prime advantage of attached growth processes is the handling of higher organic loadings due to uncoupling of mean cell residence time (MCRT) from HRT (Hassard et al., 2015).

RBC produces fewer and more concentrated sludge as compared to AS process. Due to this, a smaller secondary clarifier is required for the settling of the sludge. The size of the floc is larger in RBC due to the attached biodegrading of the organic matter as compared to the suspended 
growth process. The volume of sludge is less in RBC due to the longer solids/sludge retention time. It is evident from the literature that sludge volume is about $10 \%$ to $20 \%$ less than conventional AS process.

Only relatively short hydraulic retention time (HRT) is required because of the large active surface area. High biomass concentrations are available for degradation, which reduces the sludge production and the system does not require sludge recirculation. High oxygen transfer efficiency eliminates the need of aeration to transfer the oxygen from gas to liquid phase which makes the process to run at low operational cost (Hassard et al., 2015). Land requirement is low for RBC as compared to AS process. RBC consumes about a half of energy consumption in AS process.
One greatest advantage of RBC is ease of operation. RBC operates with slight monitoring and maintenance cost is low (Cortez et al., 2008). In AS process, a portion of the settled sludge is returned from the secondary clarifier back to the aeration tank to meet the required amount of microorganisms in the bioreactor. But in RBC, thanks to the excess of microorganisms, no recirculation is required. From all of those advantages, RBC seems to be highly attractive for treating certain treatment plants for their established simplicity, low energy usage, and consistent performance.

$\mathrm{RBC}$ process is very easy to monitor and operate. Low maintenance cost of the process makes the process more feasible for large-scale applications. RBC is resistant to shock loads, which makes the process economics more profitable.
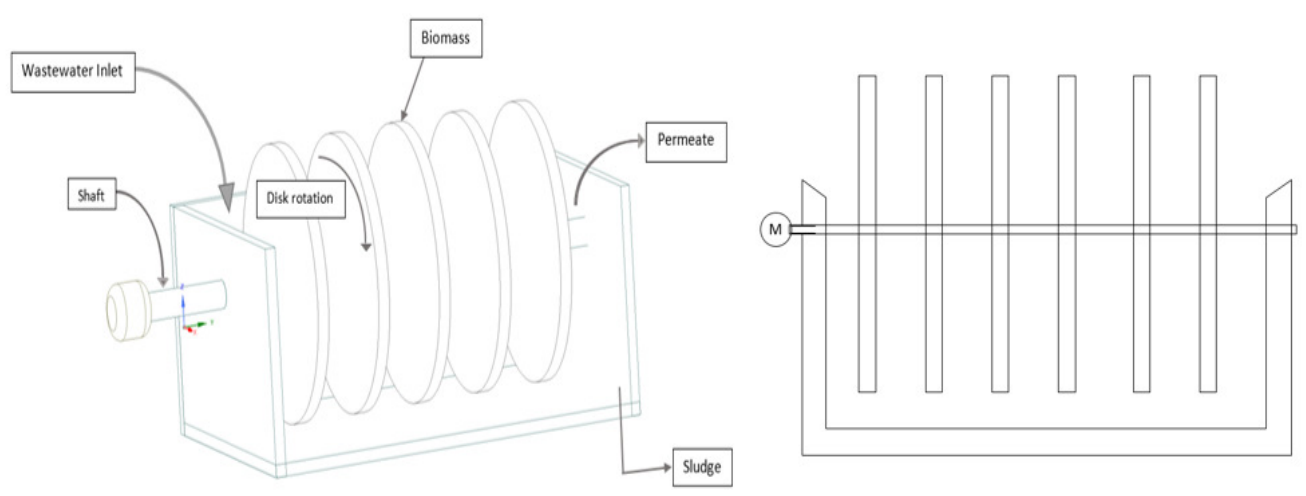

Figure 1. Schematic diagram of conventional RBC unit.

\section{FACTORS PERFORMANCES}

RBC performance depends upon numerous design parameters. The most basic parameter to affect the performance is HRT, and organic and hydraulic loading rates. It was thought in the past that these parameters only govern the performance of the treatment plant. A detailed study on the process evolved that a variety of factors contribute in the overall performance and the relationship between these parameters establish the overall behavior of the treatment process. The main parameters of importance are rotational speed, HRT, hydraulic loading rate (HLR), organic loading rate (OLR), disk media, wastewater characteristics, temperature, types of microorganisms, dissolved oxygen (DO), media submergence, step-feeding, and sludge recirculation.

\subsection{Rotational speed}

Rotational speed is directly related to the DO levels in the wastewater. As the rotational speed increases, the DO level also increases. This is due the fact that with the 
rise in rotational speed, the contact of microorganisms with the air increases resulting in the increased level of oxygen. This increases the degradation of substrate and results in the increased performance of the bioreactor rate (Israni et al., 2002). However, more power is consumed with the increase in rotational speed which can affect the economics of the treatment process. With the rise in rotational speed, microorganisms can detach from the media surface and deteriorate the effluent which results in poor treatment. Low rotational speed results in reduced DO in the bioreactor slowing the degradation process (Ramsay et al., 2006).

Due to the larger surface area, packed supports provide more oxygenation as compared to disk media for the same value of rotational speed but energy consumption will be more due to the large surface area. An optimum value of rotational speed must be chosen in order to get the proper effluent quality and economics of the process.

\subsection{Organic loading rate}

The organic loading rate was thought to be one of the main parameter controlling the treatment process. OLR is varied by fluctuating the inlet flow rate or the HRT, which also changes the HLR (Najafpour et al., 2005). With the increase in OLR, the removal efficiency decreases but substrate removal rate increases. This reduction in removal efficiency is due to the limitation of DO. More loading increases the process of degradation, increasing the need of DO in the bioreactor. The depletion of DO gradually slows the process of degradation and results in inadequate treatment.

In the first stage of RBC, carbonaceous substances are mainly removed resulting in depletion of DO. To avoid the problem of limited oxygen levels, first stage OLR must be controlled and set according to the capacity of the system. High loading could result in problems like sub-standard treatment, DO depletion, excessive biofilm thickness, odor problems, decline in process performance, and growth of unwanted microorganism, Beggiatoa $s p$.

\subsection{Hydraulic loading rate}

Historically, RBC performance has been correlated with HLR. HLR plays an important role in defining the performance of the bioreactor. Increasing the flow rate of the influent, reduces the retention time of wastewater which results in poor treatment efficiency. In a well-defined system, increase in HLR leads to an increase of microorganisms in the bioreactor (Alemzadeh and Vossoughi, 2001). Hydraulic loading is coupled with effluent quality, substrate, and the design of the RBC. RBC developers plot the hydraulic loading against effluent quality to depict the importance of parameter. These graphs can be useful in characterizing the full-scale system and for the up-gradation of lab-scale systems. The presence of large amount of microorganisms in the bioreactor offers excellent stability under toxic and high loadings (Sirianuntapiboon, 2006).

\subsection{Hydraulic retention time}

$\mathrm{HRT}$ is directly related with the organic and hydraulic loading of the influent wastewater. Longer HRT facilitates proper degradation of the substrate substances and improved removal efficiencies (Hanhan et al., 2005; Najafpour et al., 2006). The trend remains the same for toxic and heavy metal substrates (Costley and Wallis, 2000; Majumder and Gupta, 2007; Sirianuntapiboon and Chuamkaew, 2007). Short HRT will result in poor treatment process due to improper degradation of the substrate while longer HRT will affect the economics of the process. The selection of the optimized HRT is very important in 
obtaining the desired effluent quality at the minimal cost (Costley and Wallis, 2000).

\subsection{Media}

RBC media is one of the main parameter that affects the performance of the system. Different types of media are in use to stretch extra surface area per unit volume. The more the area per unit volume of the media, more microorganisms can grow and this increase the removal efficiency. However, the cost of the media should be considered while selecting one (Ware et al., 1990).

RBC media is produced from highdensity polyethylene (HDPE), Styrofoam, polycarbonate sheets, and others. HDPE is most commonly used material as media and is fabricated in different shapes and configurations according to the requirement of the process (Rodgers and Zhan, 2003; Ware et al., 1990). The configuration offers the advantage of improved mass transfer, enhanced structural stability and increased surface area.

\subsection{Staging}

$R B C$ media is designed in different stages to maximize the removal of $\mathrm{BOD}_{5}$ and nitrogen substances. Staging can be accomplished by introducing baffles in the tank or by using a series of tanks. For the secondary treatment applications, minimum number of three stages are recommeded for the proper treatment. Nitrification/denitrification and $\mathrm{BOD}_{5}$ combine required atleast four stages per flow. Small plants can be run by connecting all stages to a single shaft which is parallel to the flow direction. In large installments, one or more shaft are mounted perpendicular to the flow dreaction enploying several stages in series. The system is designed in a manner that as the wastewater flows through the bioreactor, each stage entertains an influent with an organic loading lower than the preceding stage. The first stage removes organics because of the faster growth of heterotrophic bacteria rather than nitritiers. The removal of ammonia and other nitrogen compounds occur in the last stages of the bioreactor to produce nitrates as final product.

\subsection{Wastewater characteristics}

The influent wasteawter concentration and presence of different substances is very important considering the operation of bioreactor. The flow stream with large amount of substrates may take longer retention times and the flux may be smaller. Presence of particulate matter tends to reduce the flux into the biofilm because they occupies space and hence decreases the rate of degradation. The presence of sulphide in the wastewater or its growth into the biofilm will favour the development of sulphideoxidizing bacteria which cause oxygen depletion in the system decreasing the peformance. Beggiatoa $s p$. is one type of sulphide-oxidizing bacteria that competes with hetrotrophic bacteria for oxygen and hence shifting the process from organics removal to nitrites removal. In extreme cases, Beggiatoa will take over the first stage, shifting the organics to the next stage and subsequently taking over the whole process (Mba et al., 1999).

\subsection{Dissolved oxygen levels}

In RBC, the rotation of the disk allows the biofilm to come in-contact with the air. The exposure of biofilm to the air can be controlled by submergence of the disks in the wastewater. The continuous rotation of the disk exposes the biofilm to wastewater and atmospheric oxygen. The transfer of oxygen occurs in three ways: (i) by direct contact of air and water at the air-water interface, (ii) oxygen adsorption by the liquid film attached to the media surface when it is in air, and (iii) by microorganisms when they are exposed to air.

In the initial stages of the bioreactor, DO concentrations touches minimal lavels, 
which tends to increase during the last stages when substrate concentrations are low. Usually, an increase in rotaitonal speed results in increased DO levels. oxygen transfer capacity is also increased with increase in rotaitonal speed (Rodgers and Zhan, 2003). In an aerobic reactor; During the carbonaceous oxidation step and nitirfication process; DO levels plays an important role in defining the performance. A supplementary oxygen source can be installed to account for the required amount of oxygen for degration process (Rodgers and Zhan, 2003; Surampalli and Baumann, 1997).

\subsection{Step-feeding}

In order to avoid depleted levels of DO in the bioreactor, influent wastewater is stepfeed into the system. This process of stepfeeding not only accomplish adequate DO levels in the wastewater and incrases the process capacity. Shock laodings can be avoided by this method and to have a more robust performance of the bioreactor (Janczukowicz and Klimiuk, 1992; Saikaly and Ayoub, 2003).

\section{DRAWBACKS}

RBC has a few drawbacks which include: slow process start-up, requiring adequate primary pre-treatment, requiring secondary clarifier, limited process flexibility and difficult to scale-up. In comparison to MBR, $\mathrm{RBC}$ offers lower effluent quality and lower removal efficiency.

In RBC, a specific thickness of biofilm is necessary to start the process and to sufficiently digest the organic matter in wastewater. This layer of microorganisms develops with time and delays the process start-up (approximately 3-6 months). Adequate primary pre-treatment is also essential to remove the large solid particles. Digestion of organic matter follows at the attached media and extra sludge is produced at the surface of the media. This extra sludge produced hinders the way of oxygen transfer and reduces the efficiency of the process. Detachment of this layer from the media is done by shear forces. Settling of the detached sludge is necessary to achieve the desired effluent quality of water. A secondary clarifier is attached to the RBC to settle the sludge produced and to achieve the desired effluent quality.

RBC has limited process flexibility, as it restricts the removal of multiple materials with the same microorganisms. Industrial and municipal wastewater contains various types of organic matter, nutrients, carbohydrates, proteins, and fats. A wide range of microorganisms is required to degrade these all types of wastewater to ensure the better effluent quality. Microorganisms digest the type of food that is favorable for them (Peavy et al., 1985). The choice of the microorganisms is specific to the characteristics of the influent wastewater. A variety of microorganisms are available for the removal of a wide range of materials but selection of best microorganisms to digest the food is very important parameter. In this regard, a number of parameters incorporates in the scale-up of RBC such as hydrodynamics, hydraulic flow, organic loading, oxygen transfer, active media surface area, microorganism growth and detachment from the biofilm. The developed models only consider one of the parameter and does not include the relationship between different parameters governing the process. Dutta et al. (2007) fabricated three different RBC to distinguish the oxygen transfer coefficient at different levels. But, while considering the scale up of bio reactor, the oxygen transfer should be appropriately characterized. Empirical design parameters have been developed. But, they do not exactly address the same process conditions as in the labscale. 


\section{RBC VERSUS OTHER WASTEWATER TREATMENT SYSTEMS}

RBC provides adequate treatment quality when operated according to the requirement. It provides better effluent quality and excellent controls as compared to AS process. A comparison of different parameters for RBC, activated sludge (AS) process, and membrane bioreactor (MBR) is given in Table 1. RBC and AS process both produce high quality effluents but RBC can handle toxic and shock hydraulic and organic loadings in treating wastewater. The overall removal efficiency is about $99 \%$ for organic removal and $90 \%$ for nitrogen removal in RBC . The production of sludge is low because of the attached and excess growth of microorganisms. The operating cost of RBC is low; which makes the process cost effective; because of no need of aeration.

\section{OTHER BIOLOGICAL TREATMENT SYSTEMS}

A hybrid system usually consists of two or more sources or methods used together. In terms of wastewater hybrid systems, there are various types of possible combination methods used for wastewater treatment. Hybrid systems are common to achieve the desired quality of the effluent wastewater at minimum cost.

These include moving bed biofilm reactor (MBBR), integrated fixed-film activated sludge (IFAS), fluidized bed bioreactor (FBBR) and membrane bioreactor (MBR). Hybrid activated sludge/MBBR process have been investigated for treatment of municipal wastewater in cold climates (Di Trapani et al., 2011). In MBBR process, small cylinder-shaped polyethylene media elements are placed in the aeration tank to support biofilm support. A perforated plate is installed at the outlet of the tank to prevent the discharge of media with the effluent. The media acts as carrier to the biofilm and is distributed evenly throughout the aerated tank. Advantages of the MBBR process include: no backwash requirement, no clogging, sludge recirculation is not required, and high specific biofilm surface (Andreottola et al., 2003; Ødegaard et al., 1994).

In the IFAS process, a fixed packing material is placed in an activated sludge reactor. The packing can be in the form of frames, foam pads, etc. suspended in the aeration tank. The process is different from MBBR as it uses return sludge flow. The purpose of fixed film medium is to increase the microorganism concentration in the bioreactor. This increases the capacity of the bioreactor without increasing the reactor volume (Randall and Sen, 1996).

In the FBBR, wastewater enters from the bottom of the aeration tank and flows upward through a bed of sand or activated carbon. Activated carbon is usually used since it can be prepared from various organic materials (Anshar et al., 2016 ; Nandiyanto et al., 2017 ; Nandiyanto et al., 2018 ), provides both adsorption properties and media surface for the growth of microorganisms. Effluent recirculation is performed to provide the fluid velocity with the necessary detention times. FBBR offer advantages of long SRT, ability to handle shock loads, produces high quality effluent, and operation is simple and reliable. Forward osmosis (FO) is another membrane process that can separate a concentrated and diluted solution. The permeability of water is due to the osmotic pressure applied across the membrane (Bilad, 2016).

The purpose of forming a hybrid process is to diminish the disadvantages of both the process and to increase the quality of effluent water. RBC is combined with another unit operation to improve the stability of the process against variable loading and improve the effluent standard. Most common configurations of hybrid systems in practice include a RBC/biofilm system . RBC/biofilm system has been applied to improve discharge quality and provide a flow buffer for shock loading. Combining RBC/AS is also common practice. 
Table 1. Comparison of different biological treatment processes.

\begin{tabular}{|c|c|c|c|}
\hline Parameter & Activated Sludge & RBC & MBR \\
\hline $\begin{array}{l}\text { Ease of } \\
\text { Operation }\end{array}$ & $\begin{array}{l}\text { Simple operation but } \\
\text { required continuous } \\
\text { monitoring (Gupta and } \\
\text { Bhardwaj, 2016). }\end{array}$ & $\begin{array}{l}\text { Simple operation requiring } \\
\text { less maintenance and } \\
\text { monitoring. No complex } \\
\text { process parameter is } \\
\text { involved. }\end{array}$ & $\begin{array}{l}\text { Simple operation but requires } \\
\text { continuous monitoring and } \\
\text { maintenance to avoid } \\
\text { membrane fouling. }\end{array}$ \\
\hline $\begin{array}{l}\text { Aeration } \\
\text { Requirement }\end{array}$ & $\begin{array}{l}\text { Oxygen supplied by } \\
\text { mechanical or diffused } \\
\text { air aeration. }\end{array}$ & $\begin{array}{l}\text { Oxygen is supplied by } \\
\text { contact of rotating contactor } \\
\text { with air. }\end{array}$ & $\begin{array}{l}\text { Oxygen supplied by either } \\
\text { mechanical or diffused air } \\
\text { aeration. }\end{array}$ \\
\hline TN and TP & $\begin{array}{l}\text { Can remove } \mathrm{N} \text { and } \\
\text { related compounds by } \\
\text { nitrification and } \\
\text { denitrification. }\end{array}$ & $\begin{array}{l}\text { The overall removal } \\
\text { efficiency was } \\
\text { approximately } 99 \% \text { for } \\
\text { organics removal and } 90 \% \\
\text { for nitrogen removal } \\
\text { (Trikoilidou et al., 2016). } \\
\text { Complete nitrification and } \\
\text { denitrification is achievable } \\
\text { in anaerobic RBC. }\end{array}$ & $\begin{array}{l}\text { On average, the removal } \\
\text { efficiency for TN and TP was } \\
83 \% \text { and } 55 \% \text { respectively, } \\
\text { with } 8-15 \mathrm{~h} \mathrm{HRT} \text { and a very } \\
\text { long SRT (Yeom et al., 1999). }\end{array}$ \\
\hline $\begin{array}{l}\text { Sludge } \\
\text { production }\end{array}$ & $\begin{array}{l}\text { High production of } \\
\text { sludge }\end{array}$ & $\begin{array}{l}\text { Low sludge production due } \\
\text { to high biomass } \\
\text { concentration (Safa et al., } \\
\text { 2014). }\end{array}$ & $\begin{array}{l}\text { Endogenous respiration of a } \\
\text { microbial community in MBR } \\
\text { can be encouraged by very } \\
\text { high sludge age, i.e., high } \\
\text { sludge concentration. Low } \\
\text { sludge volume index as } \\
\text { compared to AS process due } \\
\text { to the retention of sludge at } \\
\text { the surface of the membrane. }\end{array}$ \\
\hline $\begin{array}{l}\text { Energy } \\
\text { Requirement }\end{array}$ & $\begin{array}{l}\text { High energy } \\
\text { consumption }\end{array}$ & $\begin{array}{l}\text { Low energy consumption } \\
\text { because no aeration is } \\
\text { required in the bioreactor } \\
\text { (Hassard et al., 2015). }\end{array}$ & $\begin{array}{l}\text { Adequate energy } \\
\text { requirement. Energy } \\
\text { associated with aeration } \\
\text { accounts to about } 50 \% \text { of the } \\
\text { total energy input. }\end{array}$ \\
\hline $\begin{array}{l}\text { Solids } \\
\text { Retention Time }\end{array}$ & $\begin{array}{l}\text { High solids retention } \\
\text { time }\end{array}$ & $\begin{array}{l}\text { High solids retention time } \\
\text { decreases the amount of } \\
\text { sludge and large floc size } \\
\text { facilitates the settling } \\
\text { process. }\end{array}$ & $\begin{array}{l}\text { High solids retention time } \\
\text { facilitates the amount of } \\
\text { microorganisms in the } \\
\text { bioreactor. The average } \\
\text { sludge retention time is } 30 \\
\text { days (Grelier et al., 2006). }\end{array}$ \\
\hline $\begin{array}{l}\text { Hydraulic } \\
\text { Retention Time }\end{array}$ & $\begin{array}{l}\text { High HRT compared to } \\
\text { RBC }\end{array}$ & $\begin{array}{l}\text { Short HRT of about } 4 \mathrm{~h} \text { was } \\
\text { used for the removal of } \\
\text { organic matter. This is } \\
\text { because of the large amount } \\
\text { of microorganisms available } \\
\text { for digestion of organic } \\
\text { matter (Kapoor et al., 2003). }\end{array}$ & $\begin{array}{l}\mathrm{HRT}=8 \mathrm{~h} \text { and } \mathrm{T}=25^{\circ} \mathrm{C} \text { are the } \\
\text { preferred operating } \\
\text { conditions, resulting in high } \\
\text { flow rate and low membrane } \\
\text { fouling (Hemmati et al., } \\
\text { 2012). }\end{array}$ \\
\hline Land Required & Large area is required & $\begin{array}{l}\text { About } 1 / 10^{\text {th }} \text { land is required } \\
\text { as compared to AS process } \\
\text { (Cortez et al., 2008). }\end{array}$ & $\begin{array}{l}\text { Due to the low volume of } \\
\text { sludge, land requirement is } \\
\text { minimum as compared to AS } \\
\text { process. }\end{array}$ \\
\hline
\end{tabular}


Table 1 (continue). Comparison of different biological treatment processes.

\begin{tabular}{|c|c|c|c|}
\hline Parameter & Activated Sludge & RBC & MBR \\
\hline $\begin{array}{l}\text { Organic } \\
\text { Loading Rate }\end{array}$ & $\begin{array}{l}\text { Sensitive to OLR due to } \\
\text { less amount of } \\
\text { microorganisms present. }\end{array}$ & $\begin{array}{l}\text { OLR of } 24 \mathrm{~g} C O D / \mathrm{m}^{2} / \text { day was } \\
\text { used (Al-Ahmady, 2005). }\end{array}$ & $\begin{array}{l}\text { OLR ranging from } 5 \text { to } 12 \mathrm{~kg} \\
\text { COD } / \mathrm{m}^{3} \mathrm{~d}^{1} \text { (Wijekoon et al., } \\
\text { 2011). }\end{array}$ \\
\hline Aeration Cost & About $55 \%$ of the OPEX & $\begin{array}{l}\text { No aeration is required due } \\
\text { to the rotation of the shaft. }\end{array}$ & $\begin{array}{l}\text { At low MLSS, aeration cost is } \\
\text { low which tend to increase } \\
\text { with the rise in MLSS. } \\
\text { Aeration cost account to } \\
\text { about } 50 \% \text { of the operational } \\
\text { expenditure in MBR because } \\
\text { excessive aeration is required } \\
\text { (Yoon et al., 2004). }\end{array}$ \\
\hline $\begin{array}{l}\text { COPEX and } \\
\text { OPEX }\end{array}$ & High COPEX and OPEX & $\begin{array}{l}\text { An RBC was found to be on } \\
\text { average } 35 \% \text { cheaper per } \\
\text { year compared to trickling } \\
\text { filters due to lower land area } \\
\text { and running costs (Hassard et } \\
\text { al., 2015). }\end{array}$ & $\begin{array}{l}\text { COPEX is equal to the RBC } \\
\text { process but OPEX is high } \\
\text { because of aeration and } \\
\text { membrane fouling. }\end{array}$ \\
\hline $\begin{array}{l}\text { Primary } \\
\text { Treatment } \\
\text { Requirement }\end{array}$ & $\begin{array}{l}\text { Adequate primary } \\
\text { treatment is required. }\end{array}$ & $\begin{array}{l}\text { Adequate primary treatment } \\
\text { is required. }\end{array}$ & $\begin{array}{l}\text { Adequate primary treatment } \\
\text { is required in order to reduce } \\
\text { membrane fouling. }\end{array}$ \\
\hline $\begin{array}{l}\text { Secondary } \\
\text { Clarifier } \\
\text { Requirement }\end{array}$ & $\begin{array}{l}\text { Secondary clarifier is } \\
\text { required for the settling } \\
\text { of sludge. }\end{array}$ & $\begin{array}{l}\text { Integral RBC does not require } \\
\text { secondary clarifier (Hassard } \\
\text { et al., 2015). }\end{array}$ & $\begin{array}{l}\text { No need for secondary } \\
\text { clarifier because membrane } \\
\text { will retain the organic matter, } \\
\text { microorganisms and waste } \\
\text { materials. }\end{array}$ \\
\hline Scale-Up & $\begin{array}{l}\text { Easy to scale-up. } \\
\text { Adopted for any size of } \\
\text { community. }\end{array}$ & $\begin{array}{l}\text { RBC is difficult to scale-up } \\
\text { (Hassard et al., 2015). }\end{array}$ & $\begin{array}{l}\text { Scale-up is easy but should } \\
\text { account for the COPEX and } \\
\text { OPEX. }\end{array}$ \\
\hline $\begin{array}{l}\text { Sludge volume } \\
\text { index }\end{array}$ & $\begin{array}{l}\text { High sludge volume } \\
\text { index values in the } \\
\text { secondary clarifier. }\end{array}$ & $\begin{array}{l}\text { Low sludge volume index } \\
\text { values in the secondary } \\
\text { clarifier. }\end{array}$ & $\begin{array}{l}\text { Low sludge volume index } \\
\text { values are obtained due to } \\
\text { efficient membrane } \\
\text { treatment. }\end{array}$ \\
\hline Shock Loading & Sensitive to shock loads. & $\begin{array}{l}\text { Resistant to load variations. } \\
\text { Addition of staging dampens } \\
\text { shock loading. }\end{array}$ & $\begin{array}{l}\text { Adequate resistance to shock } \\
\text { loads as long as it does not } \\
\text { increase the membrane } \\
\text { fouling. }\end{array}$ \\
\hline $\begin{array}{l}\text { Sludge } \\
\text { Properties }\end{array}$ & $\begin{array}{l}\text { The settling properties } \\
\text { of sludge is not always } \\
\text { easy to control. }\end{array}$ & $\begin{array}{l}\text { Good settling characteristics } \\
\text { of the sludge. }\end{array}$ & $\begin{array}{l}\text { Sludge particles have small } \\
\text { size which makes the settling } \\
\text { process long and may affect } \\
\text { the effluent quality. }\end{array}$ \\
\hline $\begin{array}{l}\text { Recycling of } \\
\text { Sludge }\end{array}$ & $\begin{array}{l}\text { Sludge recycled to AS } \\
\text { process. }\end{array}$ & $\begin{array}{l}\text { No recycling of sludge is } \\
\text { required because excess } \\
\text { quality of microorganisms is } \\
\text { available in the bioreactor. }\end{array}$ & $\begin{array}{l}\text { Recycling of sludge is required } \\
\text { to fulfil the concentration of } \\
\text { microorganisms in the } \\
\text { bioreactor. }\end{array}$ \\
\hline
\end{tabular}


After the treatment process, RBC is installed (as a polishing unit), increasing the effluent quality (Hoyland et al., 2010). A hybrid RBC process improves the stability of the process against shock and toxic loads, increase the hydraulic load capacity of the process, and improve the achievable effluent quality (Hoyland et al., 2010).

\subsection{Membrane bioreactor}

In the last decade, MBR has emerged as a mature technology competing with other conventional wastewater treatment processes. An MBR is the combination of a membrane process (microfiltration or ultrafiltration) with a biological wastewater treatment process (Vanysacker et al., 2014). The prominent feature of MBR process is the better quality effluent and high removal efficiency which makes the process much more attractive (Leiknes and $\varnothing$ degaard, 2007; Yan et al., 2012). Compared to AS process, MBR offers several advantages which includes good disinfection capability, small footprint, less sludge production and high hydraulic loading (Yan et al., 2012).

The membrane unit either can be external or submerged into the bioreactor . For the side-stream configuration, deposition of suspended solids at the surface of the membrane is reduced by high crossflow fluid velocity. This process is easy to control and membrane fouling is reduced by high crossflow fluid velocity but it is not economically feasible. High energy input makes the operational cost of the system much higher. Submerged systems, on the other hand, are economical but due to deposition of solids at the surface of the membrane, membrane fouling is the main issue (Akhondi et al., 2017 ). Submerges system utilizes about half the energy input as compared to the side-stream system . Submerged system operates at lower permeate flux due to reduced trans membrane pressure. This lower permeate flux increases the requirement for membrane surface area (Wang et al., 2008).
MBR is a robust technology as it offers a greater removal efficiency and better effluent quality but membrane fouling restricts the performance of the membrane system. It reduces the flux, sustainability of process, increases the cleaning intervals, and ultimately increases the operational cost of the whole process (Bilad et al., 2016; Bilad, 2017).

Aeration is applied to keep the microorganisms in suspension and to limit membrane fouling at the liquid- membrane interface. Aeration consumes a major portion of operational cost and yet does not results in restraining the fouling problems. Magnetically induced membrane vibration (MMV) is an alternating process to aeration which showed improved permeability, proficient fouling control and substantial energy saving (Bilad et al., 2012; Mertens et al., 2018). MBR is effective for the treatment of high-strength industrial wastewater. Molasses containing wastewater is considered high-strength industrial wastewater due to high COD and low biodegradability. The results showed an effective removal of $80 \%$ COD, $90 \%$ TN, and $30 \%$ color while treated with lab-scale MBR (Bilad et al., 2011).

The overall performance of MBR is influenced by several factors such as membrane characteristics, operational parameters, and feed and biomass characteristics. Membrane undergoes severe drawback of membrane fouling that affects the membrane performance, decrease the membrane life-span and increases the operational cost (Bilad et al., 2014).

\section{RBC NOVEL APPLICATIONS}

RBC provides a platform for generating energy from treating wastewater. A variety of novel processes has be applied to generate direct electricity or energy production through biogas (Sayess et al., 2013). Empirical relationships and curves have been developed that are used to design the domestic and industrial wastewater 
treatment systems. However, experimental data is required for different substrate substances to apply at pilot scale. Empirical relations may not produces the best results when applied at large scale. In the RBC system, the type of substrate, rotational speed, degree of submergence, number of stages, and dimensions of media are important parameters to consider to achieve optimal results. Hydrodynamics and kinetics of the process and development of biofilm should take into account while designing an industrial wastewater treatment system.

RBC system must be supported with primary treatment devices and secondary settler. An effective primary treatment removes grit, debris and grease which reduces the load on the bioreactor. The media material should be non-corrosive, resistant to environmental conditions. The performance can be enhanced with the use of supplemental aeration, baffles, and stepfeeding.

\section{CONCLUSION}

RBC has been proved a prominent treatment process for removing $\mathrm{BOD}_{5}$ and ammonia. The attached growth of microorganisms provides large surface area for the biodegradation of organic matter. $\mathrm{RBC}$ is a predominant alternative process due to the large volumetric rate, large microbial surface area, low sludge production, and less operational and maintenance cost.
The parameters, like rotational speed, HRT, organic and hydraulic loading, DO levels, RBC media, biofilm, and waste water properties should be carefully monitored to get desired effluent quality. Thermodynamics, bio- and chemical kinetics, and biofilm characteristics need to be fully understand to fully master the RBC design. Aerobic and anaerobic RBC can be operated to achieve nitrification or denitrification. Anaerobic RBC showed the promising results for effective removal of high strength organic wastewater and nitrification/denitrification. On the lab-scale, anoxic RBC showed high nitrate removal efficiencies. Anaerobic/anoxic RBC can be used for the removal of high strength industrial wastewater and for the removal of pharmaceutical chemical. Knowledge of the dependence of various parameters on one another and improvements in disk material, supplementary aeration, and step-feeding can result in efficient treatment of wastewater.

\section{ACKNOWLEDGEMENTS}

The authors acknowledge Universiti Teknologi PETRONAS for providing facilities for conducting the research activities.

\section{AUTHORS' NOTE}

The author (s) declare (s) that there is no conflict of interest regarding the publication of this article. Authors confirmed that the data and the paper are free of plagiarism.

\section{REFERENCES}

Akhondi, E., Zamani, F., Tng, K. H., Leslie, G., Krantz, W. B., Fane, A. G., and Chew, J. W. (2017). The Performance and Fouling Control of Submerged Hollow Fiber (HF) Systems: A Review. Applied Sciences, 7(8), 765.

Al-Ahmady, K. K. (2005). Effect of organic loading on rotating biological contactor efficiency. International Journal of Environmental Research and Public Health, 2(3), 469-477.

Alemzadeh, I., and Vossoughi, M. (2001). Biodegradation of toluene by an attached biofilm in a rotating biological contactor. Process Biochemistry, 36(8-9), 707-711. 
253 | Indonesian Journal of Science \& Technology, Volume 4 Issue 2, September 2019 page 241-256

Andreottola, G., Foladori, P., Gatti, G., Nardelli, P., Pettena, M., and Ragazzi, M. (2003). Upgrading of a small overloaded activated sludge plant using a MBBR system. Journal of Environmental Science and Health: Part A, 38(10), 2317-2328.

Anshar, A. M., Taba, P., and Raya, I. (2016). Kinetic and Thermodynamics Studies the Adsorption of Phenol on Activated Carbon from Rice Husk Activated by $\mathrm{ZnCl} 2$. Indonesian Journal of Science and Technology, 1(1), 47-60.

Bilad, M., Arafat, H. A., and Vankelecom, I. F. (2014). Membrane technology in microalgae cultivation and harvesting: a review. Biotechnology Advances, 32(7), 1283-1300.

Bilad, M., Baten, M., Pollet, A., Courtin, C., Wouters, J., Verbiest, T., and Vankelecom, I. F. J. (2016). A novel In-situ Enzymatic Cleaning Method for Reducing Membrane Fouling in Membrane Bioreactors (MBRs). Indonesian Journal of Science and Technology, 1(1), 1-22.

Bilad, M. R. (2016). Module-Scale Simulation of Forward Osmosis Module-Part A: Plate-andFrame. Indonesian Journal of Science and Technology, 1(2), 249-261.

Bilad, M. R. (2017). Membrane bioreactor for domestic wastewater treatment: principles, challanges and future research directions. Indonesian Journal of Science and Technology, 2(1), 97-123.

Bilad, M. R., Declerck, P., Piasecka, A., Vanysacker, L., Yan, X., and Vankelecom, I. F. (2011). Treatment of molasses wastewater in a membrane bioreactor: influence of membrane pore size. Separation and Purification Technology, 78(2), 105-112.

Bilad, M. R., Mezohegyi, G., Declerck, P., and Vankelecom, I. F. (2012). Novel magnetically induced membrane vibration (MMV) for fouling control in membrane bioreactors. Water Research, 46(1), 63-72.

Chan, R. T., and Stenstrom, M. K. (1981). Use of the rotating biological contactor for appropriate technology wastewater treatment: UC Appropriate Technology Program, University of California, Davis.

Cortez, S., Teixeira, P., Oliveira, R., and Mota, M. (2008). Rotating biological contactors: a review on main factors affecting performance. Reviews in Environmental Science and BioTechnology, 7(2), 155-172.

Costley, S., and Wallis, F. (2000). Effect of flow rate on heavy metal accumulation by rotating biological contactor (RBC) biofilms. Journal of Industrial Microbiology and Biotechnology, 24(4), 244-250.

Di Trapani, D., Christensso, M., and Ødegaard, H. (2011). Hybrid activated sludge/biofilm process for the treatment of municipal wastewater in a cold climate region: a case study. Water Science and Technology, 63(6), 1121-1129.

Doman, J. (1929). Results of operation of experimental contact filter with partially submerged rotating plates. Sewage Works Journal, 555-560.

Findlay, G. (1993). The selection and design of rotating biological contactors and reed beds for small sewage treatment plants. Proceedings of the Institution of Civil Engineers-Water Maritime and Energy, 101(4), 237-246.

Grelier, P., Rosenberger, S., and Tazi-Pain, A. (2006). Influence of sludge retention time on membrane bioreactor hydraulic performance. Desalination, 192(1-3), 10-17. 
Griffin, P., and Findlay, G. (2000). Process and engineering improvements to rotating biological contactor design. Water Science and Technology, 41(1), 137-144.

Gupta, S., and Bhardwaj, N. K. (2016). Advances in the Treatment of Pulp and Paper Mill Wastewater. Environmental Waste Management, 33, 47-72.

Hanhan, O., Orhon, D., Krauth, K., and Günder, B. (2005). Evaluation of denitrification potential of rotating biological contactors for treatment of municipal wastewater. Water Science and Technology, 51(11), 131-139.

Hassard, F., Biddle, J., Cartmell, E., Jefferson, B., Tyrrel, S., and Stephenson, T. (2015). Rotating biological contactors for wastewater treatment - A review. Process Safety and Environmental Protection, 94, 285-306.

Hemmati, A., Dolatabad, M. M., Naeimpoor, F., Pak, A., and Mohammdi, T. (2012). Effect of hydraulic retention time and temperature on submerged membrane bioreactor (SMBR) performance. Korean Journal of Chemical Engineering, 29(3), 369-376.

Hoyland, G., Vale, P., Rogalla, F., and Jones, M. (2010). A new approach to nutrient removal using the HYBACS process. Proceedings of the Water Environment Federation, 2010(7), 81-94.

Israni, S. H., Koli, S. S., Patwardhan, A. W., Melo, J. S., and D'souza, S. F. (2002). Phenol degradation in rotating biological contactors. Journal of Chemical Technology and Biotechnology: International Research in Process, Environmental and Clean Technology, 77(9), 1050-1057.

Janczukowicz, W., and Klimiuk, E. (1992). The influence of the raw wastes dosing system on technological parameters of the rotating biological disc (RBD) process. Bioresource Technology, 42(3), 241-245.

Kapoor, A., Kuiper, A., Bedard, P., and Gould, W. (2003). Use of a rotating biological contactor for removal of ammonium from mining effluents. ejmp and ep (European Journal of Mineral Processing and Environmental Protection), 3(1), 88-100.

Lee, J., Ahn, W.-Y., and Lee, C.-H. (2001). Comparison of the filtration characteristics between attached and suspended growth microorganisms in submerged membrane bioreactor. Water Research, 35(10), 2435-2445.

Leiknes, T., and $\varnothing$ degaard, H. (2007). The development of a biofilm membrane bioreactor. Desalination, 202(1-3), 135-143.

Majumder, P. S., and Gupta, S. (2007). Removal of chlorophenols in sequential anaerobicaerobic reactors. Bioresource Technology, 98(1), 118-129.

Mba, D., Bannister, R., and Findlay, G. (1999). Mechanical redesign of the rotating biological contactor. Water Research, 33(18), 3679-3688.

Mertens, M., Bilad, M. R., Gebreyohannes, A. Y., Marbelia, L., and Vankelecom, I. (2018). Membrane development for improved performance of a magnetically induced vibration system for anaerobic sludge filtration. Separation and Purification Technology, 200, 120129. 
255 | Indonesian Journal of Science \& Technology, Volume 4 Issue 2, September 2019 page 241-256

Najafpour, G., Yieng, H. A., Younesi, H., and Zinatizadeh, A. (2005). Effect of organic loading on performance of rotating biological contactors using palm oil mill effluents. Process Biochemistry, 40(8), 2879-2884.

Najafpour, G., Zinatizadeh, A., and Lee, L. (2006). Performance of a three-stage aerobic RBC reactor in food canning wastewater treatment. Biochemical Engineering Journal, 30(3), 297-302.

Nandiyanto, A. B., Putra, Z. A., Andika, R., Bilad, M. R., Kurniawan, T., Zulhijah, R., and Hamidah, I. (2017). Porous activated carbon particles from rice straw waste and their adsorption properties. Journal of Engineering Science and Technology, 12, 1-11.

Nandiyanto, A. B. D., Zaen, R., and Oktiani, R. (2018). Working volume in high-energy ballmilling process on breakage characteristics and adsorption performance of rice straw ash. Arabian Journal for Science and Engineering, 43(11), 6057-6066.

$\varnothing$ degaard, H., Rusten, B., and Westrum, T. (1994). A new moving bed biofilm reactorapplications and results. Water Science and Technology, 29(10-11), 157-165.

Patwardhan, A. (2003). Rotating biological contactors: A review. Industrial and Engineering Chemistry Research, 42(10), 2035-2051.

Peavy, D., Brunner, M., Duckworth, W., Hooker, C., and Frank, B. (1985). Receptor binding and biological potency of several split forms (conversion intermediates) of human proinsulin. Studies in cultured IM-9 lymphocytes and in vivo and in vitro in rats. Journal of Biological Chemistry, 260(26), 13989-13994.

Pebriyanti, G., Zhu, R., and Rehiara, A. B. (2016). Sludge Dewatering Process Control Using Principal Component Analysis (PCA) and Partial Least Square (PLS). Indonesian Journal of Science and Technology, 1(1), 61-73.

Poon, C. P., Chao, Y.-L., and Mikucki, W. J. (1979). Factors controlling rotating biological contactor performance. Water Pollution Control Federation, 51(3), 601-611.

Rajasulochana, P., and Preethy, V. (2016). Comparison on efficiency of various techniques in treatment of waste and sewage water-A comprehensive review. Resource Efficient Technologies, 2(4), 175-184.

Ramsay, J., Shin, M., Wong, S., and Goode, C. (2006). Amaranth decoloration by Trametes versicolor in a rotating biological contacting reactor. Journal of Industrial Microbiology and Biotechnology, 33(9), 791.

Randall, C. W., and Sen, D. (1996). Full-scale evaluation of an integrated fixed-film activated sludge (IFAS) process for enhanced nitrogen removal. Water Science and Technology, 33(12), 155-162.

Rodgers, M., and Zhan, X.-M. (2003). Moving-medium biofilm reactors. Reviews in Environmental Science and Biotechnology, 2(2-4), 213-224.

Safa, M., Alemzadeh, I., and Vossoughi, M. (2014). Biodegradability of oily wastewater using rotating biological contactor combined with an external membrane. Journal of Environmental Health Science and Engineering, 12(1), 117.

Saikaly, P., and Ayoub, G. (2003). Ammonia nitrogen removal in step-feed rotating biological contactors. Water, Air, and Soil Pollution, 150(1-4), 177-191. 
Sayess, R. R., Saikaly, P. E., El-Fadel, M., Li, D., and Semerjian, L. (2013). Reactor performance in terms of COD and nitrogen removal and bacterial community structure of a three-stage rotating bioelectrochemical contactor. Water Research, 47(2), 881-894.

Sirianuntapiboon, S. (2006). Treatment of wastewater containing $\mathrm{Cl} 2$ residue by packed cage rotating biological contactor (RBC) system. Bioresource Technology, 97(14), 1735-1744.

Sirianuntapiboon, S., and Chuamkaew, C. (2007). Packed cage rotating biological contactor system for treatment of cyanide wastewater. Bioresource Technology, 98(2), 266-272.

Surampalli, R. Y., and Baumann, E. R. (1997). Role of supplemental aeration in improving overloaded first-stage RBC performance. Water, Air, and Soil Pollution, 98(1-2), 1-15.

Teixeira, P., and Oliveira, R. (2001). Denitrification in a closed rotating biological contactor: effect of disk submergence. Process Biochemistry, 37(4), 345-349.

Trikoilidou, E., Samiotis, G., Bellos, D., and Amanatidou, E. (2016). Sustainable operation of a biological wastewater treatment plant. IOP Conference Series: Materials Science and Engineering, 161(1), 012093.

Vanysacker, L., Declerck, P., Bilad, M., and Vankelecom, I. (2014). Biofouling on microfiltration membranes in MBRs: Role of membrane type and microbial community. Journal of Membrane Science, 453, 394-401.

Wang, Z., Wu, Z., Yin, X., and Tian, L. (2008). Membrane fouling in a submerged membrane bioreactor (MBR) under sub-critical flux operation: membrane foulant and gel layer characterization. Journal of Membrane Science, 325(1), 238-244.

Ware, A., Pescod, M., and Storch, B. (1990). Evaluation of alternatives to conventional disc support media for rotating biological contactors. Water Science and Technology, 22(1-2), 113-117.

Wijekoon, K. C., Visvanathan, C., and Abeynayaka, A. (2011). Effect of organic loading rate on VFA production, organic matter removal and microbial activity of a two-stage thermophilic anaerobic membrane bioreactor. Bioresource Technology, 102(9), 53535360 .

Wiszniowski, J., Robert, D., Surmacz-Gorska, J., Miksch, K., and Weber, J. (2006). Landfill leachate treatment methods: A review. Environmental Chemistry Letters, 4(1), 51-61.

Yan, X., Bilad, M. R., Gerards, R., Vriens, L., Piasecka, A., and Vankelecom, I. F. (2012). Comparison of MBR performance and membrane cleaning in a single-stage activated sludge system and a two-stage anaerobic/aerobic (A/A) system for treating synthetic molasses wastewater. Journal of Membrane Science, 394, 49-56.

Yeom, I.-T., Nah, Y.-M., and Ahn, K.-H. (1999). Treatment of household wastewater using an intermittently aerated membrane bioreactor. Desalination, 124(1-3), 193-203.

Yoon, S.-H., Kim, H.-S., and Yeom, I.-T. (2004). The optimum operational condition of membrane bioreactor (MBR): Cost estimation of aeration and sludge treatment. Water Research, 38(1), 37-46. 